\title{
Surface-Water Radon-222 Distribution along the West-Central Florida Shelf
}

By C.G. Smith and L.L. Robbins

Open-File Report 2012-1212

U.S. Department of the Interior

U.S. Geological Survey 


\title{
U.S. Department of the Interior \\ Kenneth Salazar, Secretary
}

\author{
U.S. Geological Survey \\ Marcia K. McNutt, Director
}

U.S. Geological Survey, Reston, Virginia 2012

For product and ordering information:

World Wide Web: http://www.usgs.gov/pubprod

Telephone: 1-888-ASK-USGS

For more information on the USGS—the Federal source for science about the Earth, its natural and living resources, natural hazards, and the environment:

World Wide Web: http://www.usgs.gov

Telephone: 1-888-ASK-USGS

Suggested citation:

Smith, C.G., and Robbins, L.L., 2012, Surface-water radon-222 distribution along the west-central Florida shelf: U.S. Geological Survey Open-File Report 2012-1212, 26 p.

Any use of trade, product, or firm names is for descriptive purposes only and does not imply endorsement by the U.S. Government.

Although this report is in the public domain, permission must be secured from the individual copyright owners to reproduce any copyrighted material contained within this report. 


\section{Table of Contents}

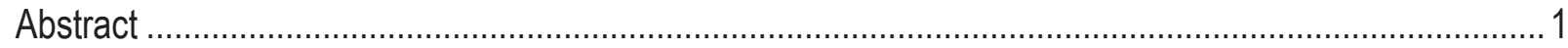

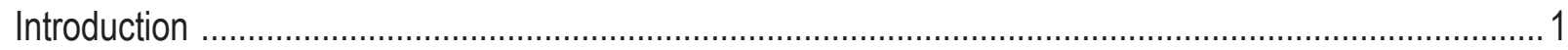

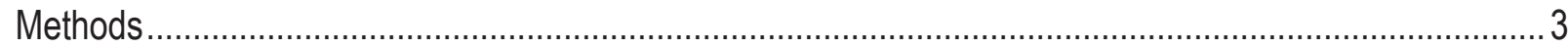

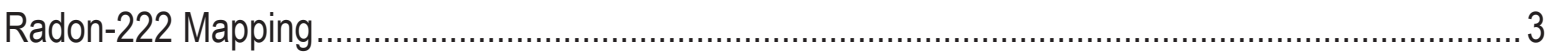

Water-Column Radon-222 Flux and Mass Balance ………..........................................................

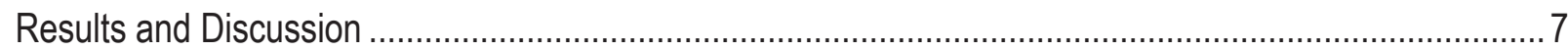

Spatial and Temporal Radon Mapping Data...........................................................................

Radon-222 Production and Decay ....................................................................................... 10

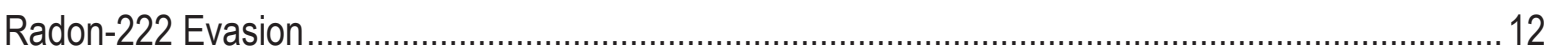

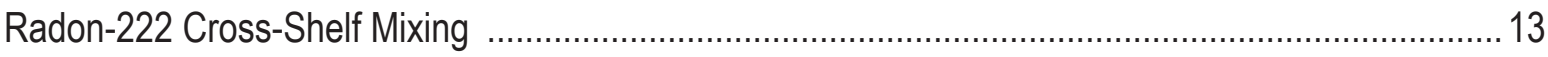

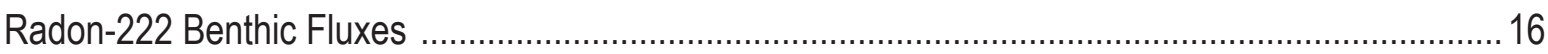

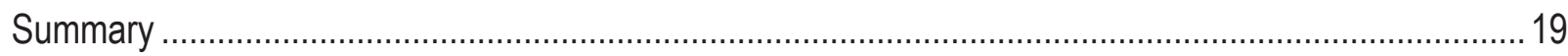

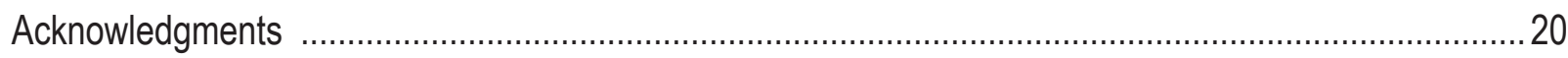

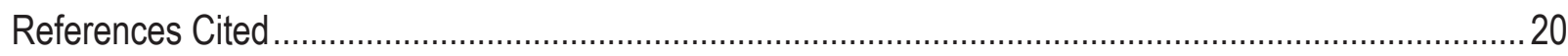

\section{Tables}

1. Summary of the boundary conditions and optimal parameters determined for the cross-shelf mixing and benthic flux model of evasion-corrected excess radon-222 inventory as a function of

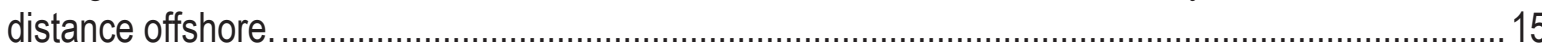

2. Summary of radon-222 fluxes $\left(B q m^{-2} \mathrm{~d}^{-1}\right)$ from several studies along the eastern and northeastern Gulf of Mexico.

\section{Figures}

1. Map showing tracklines for the February 2009 and August 2009 cruises.......................................... 4

2. Map showing surface-water radon-222 activity for the February 2009 and August 2009 cruises

3. Radon-222 activity plotted as a function of distance from the shoreline for the February 2009 and August 2009 cruises

4. Wind speed normalized to 10 meters above sea-level from NOAA Buoys 42036 and 42013 for the February 2009 and August 2009 cruises

5. Regression analysis of atmospheric evasion rates of radon-222 .................................................. 12

6. Map showing atmospheric radon-222 flux for the February 2009 and August 2009 cruises.................13

7. Atmospheric radon-222 flux plotted as a function of distance from the shoreline for the February 2009 and August 2009 cruises.

8. Evasion-corrected excess radon-222 inventories plotted as a function of distance from the shoreline for the February 2009 and August 2009 cruises. 


\section{Conversion Factors}

SI to Inch/Pound

\begin{tabular}{lcl}
\hline \multicolumn{1}{c}{ Multiply } & By & To obtain \\
\hline centimeter $(\mathrm{cm})$ & Length & \\
\hline meter $(\mathrm{m})$ & 0.39370 & inch (in.) \\
\hline kilometer $(\mathrm{km})$ & 3.28083 & feet (ft) \\
\hline & 0.62137 & \\
\hline milliliter $(\mathrm{mL})$ & Volume & ounce, fluid (fl. oz) \\
\hline liter $(\mathrm{L})$ & 0.03382 & gallon (gal) \\
\hline cubic meter $\left(\mathrm{m}^{3}\right)$ & 0.26417 & cubic foot (ft $\left.{ }^{3}\right)$ \\
\hline & 35.31446 & \\
\hline gram $(\mathrm{g})$ & Mass & ounce, avoirdupois (oz) \\
\hline becquerel $(\mathrm{Bq})$ & 0.03527 & picocurie (pCi) \\
\hline
\end{tabular}




\title{
Surface Water Radon-222 Distribution along the West-Central Florida Shelf
}

\author{
By C.G. Smith and L.L. Robbins
}

\begin{abstract}
In February 2009 and August 2009, the spatial distribution of radon-222 in surface water was mapped along the west-central Florida shelf as collaboration between the Response of Florida Shelf Ecosystems to Climate Change project and a U.S. Geological Survey Mendenhall Research Fellowship project. This report summarizes the surface distribution of radon-222 from two cruises and evaluates potential physical controls on radon-222 fluxes. Radon-222 is an inert gas produced overwhelmingly in sediment and has a short half-life of 3.8 days; activities in surface water ranged between 30 and 170 becquerels per cubic meter. Overall, radon-222 activities were enriched in nearshore surface waters relative to offshore waters. Dilution in offshore waters is expected to be the cause of the low offshore activities. While thermal stratification of the water column during the August survey may explain higher radon-222 activities relative to the February survey, radon-222 activity and integrated surface-water inventories decreased exponentially from the shoreline during both cruises. By estimating radon-222 evasion by wind from nearby buoy data and accounting for internal production from dissolved radium-226, its radiogenic long-lived parent, a simple onedimensional model was implemented to determine the role that offshore mixing, benthic influx, and decay have on the distribution of excess radon-222 inventories along the west Florida shelf. For multiple statistically based boundary condition scenarios (first quartile, median, third quartile, and maximum radon-222 inshore of 5 kilometers), the cross-shelf mixing rates and average nearshore submarine groundwater discharge (SGD) rates varied from $10^{0.38}$ to $10^{-3.4}$ square kilometers per day and 0.00 to 1.70 centimeters per day, respectively. This dataset and modeling provide the first attempt to assess cross-shelf mixing and SGD on such a large spatial scale. Such estimates help scale up SGD rates that are often made at 1- to 10-meter resolution to a coarser but more regionally applicable scale of 1- to 10-kilometer resolution. More stringent analyses and model evaluation are required, but results and analyses presented in this report provide the foundation for conducting a more rigorous statistical assessment.
\end{abstract}

\section{Introduction}

Radon-222, which has a half-life of 3.82 days $\left(\mathrm{t}_{1 / 2}=3.82 \mathrm{~d}\right)$, is a naturally occurring radionuclide that originates from the uranium-238 decay series through the alpha decay of radium-226. Radon $(\mathrm{Rn})$ behaves conservatively in most chemical reactions in nature (except weak van der 
Waal bonds). Dissimilar geochemical behaviors of radium ( $\mathrm{Ra}$ ) and $\mathrm{Rn}$ provide for a unique system where the daughter elements can easily decouple, and depending on the environment and processes (turbulent mixing, groundwater flow), either enrichment or deficiencies of the daughter isotopes relative to their radiogenic parents are likely. Due to its utility more so than its ease of measurement, radon-222 has been used to quantify benthic exchange (Broecker and others, 1967; Clements and Wilkening, 1974; Hammond and others, 1977; Gruebel and Martens, 1984; Hoehn and others, 1992; Bertin and Bourg, 1994; Cable and others, 1996a). The recent advent of continuous radon-inair monitoring devices has allowed for increased continuous monitoring of radon-222 in coastal and shelf waters (Dulaiova and others, 2005). Because radon-222 is produced primarily by ingrowth from sediment-bound radium-226 (hereafter referred to as sedimentary production) in the natural environment, the enrichment of radon-222 in coastal waters has been linked to a phenomenon commonly referred to as submarine groundwater discharge (SGD), a form of enhanced benthic fluid flux. Submarine groundwater discharge has been implicated as a major vector, delivering trace metals, nutrients, and a variety of other dissolved constituents to the coastal region. In this study, we examine the spatial distribution of radon-222 along the west Florida shelf (WFS) and evaluate its spatial distribution in terms of potential benthic fluxes.

Submarine groundwater discharge is defined as any and all fluids discharged from benthic sediments into coastal water bodies (Burnett and others, 2003) and consists of both marine (recirculated) and terrestrial fluid sources. Submarine groundwater discharge has long been recognized as a potential vector for ecologically important and deleterious constituents to the coastal oceans (Johannes, 1980). However, it has not been until the last decade, with the advent of reliable SGD measurement techniques, that quantification of material fluxes and suggested subsequent ecological impacts have been possible. Of the two SGD components, the terrestrial fraction represents the allochthonous contribution and is the most provocative source when investigating the interactions between the ecology and hydrology in coastal systems. Human activities onshore, including on-site waste disposal and agriculture, can contribute allochthonous nutrients to the shallow coastal waters. Several studies have linked SGD to coastal nutrient loading (Hwang and others, 2005; Kroeger and others, 2007), but it has not been quantitatively determined whether SGD is directly linked to specific events such as harmful algal blooms (HABs).

Along the west Florida coast, three aquifers are exposed at or near land surface and are hydrologically connected to the coastal ocean; they are, from north to south, the Floridan aquifer, the Surficial aquifer, and the Biscayne aquifer. North of Tampa, the Floridan aquifer crops out and is recharged directly by precipitation. The Surficial aquifer is exposed at or near the land surface from south of Tampa to almost the southern tip of Florida within the Everglades National Park. The Biscayne aquifer underlies the southern portion of the Everglades National Park. Where these aquifers are exposed at the land-sea margin, they provide a potential source of submarine groundwater to the coastal ocean. In addition to this shoreline connection, several studies have shown that appreciable 
SGD occurs from submarine springs sourced primarily by the Floridan aquifer (Fanning and others, 1987). Thus, submarine groundwater may represent a formidable vector for new nutrients to the west Florida shelf.

Recent studies conducted in the Tampa Bay region of Florida have examined submarine groundwater discharge and its role in nutrient delivery to this coastal embayment (Kroeger and others, 2007; Swarzenski and others, 2007). Swarzenski and others (2007) surveyed the entire bay and found that SGD-derived total dissolved nitrogen (TDN) was on the same order of magnitude as local riverine inputs. Similarly, Kroeger and others (2007) looked at SGD-derived nutrient fluxes from the southern tip of Pinellas County into the adjacent nearshore region. Based on their results, fresh SGD delivered comparative quantities of allochthonous $\mathrm{TDN}$ and $\mathrm{PO}_{4}^{3-}$ as do local streams, while saline SGD delivered approximately 70 percent and 223 percent of TDN and $\mathrm{PO}_{4}^{3-}$, respectively, as compared to local streams (Kroeger and others, 2007). These studies show that SGD plays an important role in the nutrient delivery to this embayment and further indicate that SGD may be an important vector for nutrient delivery to the shallow WFS.

In this study, we utilize a previously unpublished dataset of over 1,000 radon-222 activity measurements made during two separate cruises (600+ in February 2009 and 400+ in August 2009) along the WFS. The objectives were to determine (1) whether the data provide insight to the physical and potentially geologic controls on radon-222 distribution across a broad shelf and (2) whether a simple parameterized model can be used to quantitatively extract meaningful rates of benthic radon-222 flux (analogy for SGD) and cross-shelf mixing. Previous investigations that utilized radon-222 to quantify these processes have been restricted to relatively small, linear scales (generally represented as a function of distance from the shoreline). Here, we build upon previous models to evaluate if and how radon-222 observations can be scaled up.

\section{Methods}

\section{Radon-222 Mapping}

Radon-222 surveys along the WFS were conducted February 23-28 and August 16-21, 2009, in collaboration with the U.S. Geological Survey Coastal and Marine Geology Program (CMGP)-funded project Response of Florida Shelf Ecosystems to Climate Change. Tracklines are shown in figure 1. Radon extraction and measurement followed the procedure of Dulaiova and others (2005). Briefly, surface water was continuously pumped ( 2 to 5 liters per minute; $\mathrm{L} \mathrm{min}^{-1}$ ) from a through-hull opening at approximately 1.5 meters $(\mathrm{m})$ below the sea surface to an air-water equilibration chamber. Radon was separated from the water into the headspace of the chamber. Using three commercially available radon-in-air detection devices with internal air pumps (RAD7, 


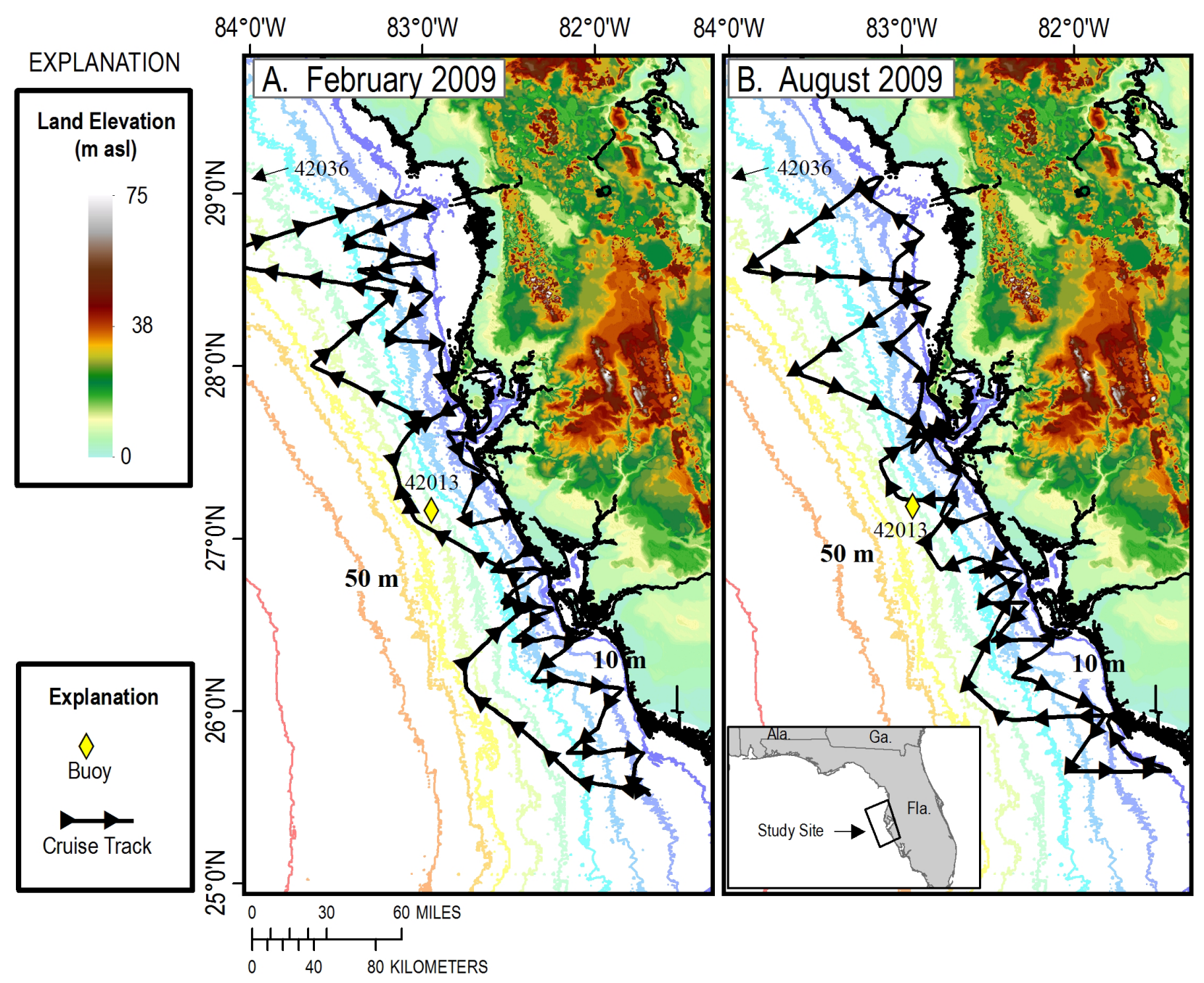

Figure 1. Map showing tracklines (black arrowheads) for the (A) February 2009 and (B) August 2009 cruises. Warmer colors on land indicate higher elevations that decrease down-gradient to greenish-blue. Colored lines beyond the shoreline (solid black line) are bathymetry, increasing from blue (shallowest) to red (deepest). Abbreviations: $m$, meter; $m$ asl, meters above sea level.

Durridge, Inc.), radon-222 in the air phase was circulated and analyzed via its short-lived decay product, polonium-218. Count integration time for both trips was $10 \mathrm{~min}$. Chamber temperature was monitored to accurately convert in-air concentrations to in-water concentrations. Based on system background count rates measured before, during, and after the cruises, the minimum detectable activity (MDA) in the system was $2.7 \pm 0.5$ becquerels per cubic meter $\left(\mathrm{Bq} \mathrm{m}^{-3}\right)(\mathrm{n}=6)$. All errors are reported to one standard deviation unless otherwise noted. In addition to radon-222, salinity and temperature were measured continuously using a flow-through conductivity and temperature probe system (YSI 6600).

Sampling density ( $\sim 0.3$ to 1 sample per kilometer) was governed by the speed of the boat ( 2.5 to 5 meters per second, $\mathrm{m} \mathrm{s}^{-1}$ ) and integration time (10 min). These measurements are much 
coarser than observed in other coastal mapping studies. Position was continuously recorded at 2-min intervals (datum WGS84) and integrated with the radon data during post-processing. Once integrated, the data were analyzed using GIS software (ESRI ArcGIS). The distance between midpoint sampling locations and shoreline (NOAA, 2012a) was determined using the built-in ArcToolbox function NEAR (ESRI). The NEAR function computes the shortest distances between two vector datasets and records the distance and angle. Given the irregularity of the shoreline, not all measurements were orthogonal to the shoreline. Assessment of potential error due to non-orthogonal measurements was determined to be less than or equal to $20 \mathrm{~m}$. Depth was extracted for each radon measurement from the National Geophysical Data Center bathymetric model for the Gulf of Mexico (NOAA, 2012b).

\section{Water-Column Radon-222 Flux and Mass Balance}

Processes affecting water-column radon-222 have been defined for a variety of coastal and deep marine settings (Broecker and others, 1967; Broecker and Peng, 1971; Peng and others, 1974; Fanning and others, 1982; Cable and others, 1996b; Colbert and others, 2008). Assuming water-column radon-222 inventories are in steady state, the balance between sources and sinks must equate to the decay-corrected water-column inventory (Craig, 1969; Cable and others, 1996b; Corbett and others, 1997). The model is often represented for a known water-column thickness ( $z$; $\mathrm{m})$ and unit area $\left(\mathrm{m}^{2}\right)$ such that the ${ }^{222} \mathrm{Rn}$ inventory $\left(I_{R n} ; \mathrm{Bq} \mathrm{m}^{-2}\right)$ in steady state is

$$
\frac{d I_{R n}}{d t}=0=J_{\text {benthic }}-J_{\text {atm }} \pm J_{\text {mix }}+\left[z\left(\lambda_{R n} A_{R a}-\lambda_{R n} A_{R n}\right)\right]
$$

where losses due to water-column mixing ( $J_{\text {mix }}$; becquerels per square meter per day, Bq $\mathrm{m}^{-2} \mathrm{~d}^{-1}$ ),

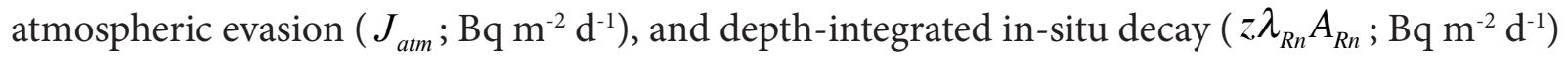
are balanced by benthic flux of ${ }^{222} \mathrm{Rn}\left(J_{\text {benthic }} ; \mathrm{Bq} \mathrm{m}^{-2} \mathrm{~d}^{-1}\right)$, depth-integrated production from ${ }^{226} \mathrm{Ra}$ $\left(z \lambda_{R n} A_{R a} ; \mathrm{Bq} \mathrm{m}^{-2} \mathrm{~d}^{-1}\right)$, and lateral inputs $\left(J_{\text {benthic }} ; \mathrm{Bq} \mathrm{m}^{-2} \mathrm{~d}^{-1}\right)$. Solving the equation for $J_{\text {benthic }}$ provides a direct estimate for total benthic fluxes, provided estimates of the other sources and sinks are available.

In well-mixed, shallow-water systems, benthic flux ( $J_{\text {benthic }}$; advection and diffusion) from sediments is the primary source of radon-222 in the water column. Additional sources of radon-222 to the offshore surface layer include mixing fluxes from the coastal zone and production from dissolved radium-226 (Cable and others, 1996b; Burnett and Dulaiova, 2003). Losses of radon-222 from the surface layer include atmospheric evasion, decay, and (or) mixing loss. While this model

is fairly simplistic, the utility of modeling radon-222 exchange and its relationship to benthic fluxes has proven quite robust. 
Atmospheric evasion $\left(J_{\text {atm }}\right.$ ) can represent a formidable loss term with respect to both coastal and open-ocean surface-water radon-222 (Peng and others, 1979; Burnett and others, 2007; Smith and others, 2011). Models of radon evasion (or atmospheric flux, $J_{\text {atm }}$ ) have been well represented in the literature and are of the form:

$$
J_{a t m}=k\left(A_{R n_{w}}-\alpha A_{R n_{a i r}}\right)
$$

where $k$ is the gas transfer coefficient $\left(\mathrm{m} \mathrm{s}^{-1}\right), A_{R n_{w}}$ and $A_{R n_{\text {air }}}$ are the radon content in the water and the air $\left(\mathrm{Bq} \mathrm{m}^{-3}\right)$, and $\alpha$ is the Ostwald solubility coefficient. In most coastal and open-ocean settings, atmospheric concentration is negligible (Burnett and others, 2007). Thus, a first-order estimate of atmospheric flux is

$$
J_{\text {atm }}=k A_{R n_{w}}
$$

Estimates of the gas transfer coefficient $[k(600)]$ generally rely on empirical formulas that are functions of wind velocity at $\left(u_{10} ; \mathrm{m} \mathrm{s}^{-1}\right)$ (MacIntyre and others, 1995):

$$
k(600)=0.45 u_{10}{ }^{1.6}(S c / 600)^{-1 / 2}
$$

where $S c$ is the Schmidt number (ratio of molecular diffusion and kinematic viscosity). The dependence of the $S c$ on temperature and salinity allows for relating the transfer to variable in-situ conditions. Wind velocity was not measured shipboard; instead, wind velocity acquired at two offshore buoys and data distributed by the National Data Buoy Center (NOAA, 2012c) were used to assess atmospheric evasion. Locations of the two buoys used in this study (Station 42021 at $28.500^{\circ} \mathrm{N}$. and $84.417^{\circ} \mathrm{W}$. and Station 42013 at $27.169^{\circ} \mathrm{N}$. and $82.926^{\circ} \mathrm{W}$.) are presented in figure 1. All data were normalized to a measurement height of $10 \mathrm{~m}$ using the power-law function presented by Hsu and others (1994).

Equations describing the offshore turbulent mixing ( $\left.K_{h} ; \mathrm{m} 2 \mathrm{~d}-1\right)$ of a conservative, short-lived radioactive tracer have been presented by Moore (2000). The general form is

$$
\frac{d}{d x}\left(K_{h} \frac{d A_{x}}{d x}\right)-\lambda A_{x}=0
$$

with the general solution for the boundary conditions $A(x=0)=A_{0}$ and $\left.\frac{d A_{x}}{d x}\right|_{L}=0$

$$
\ln \left(A_{x}\right)=\ln \left(A_{0}\right)-x \sqrt{\lambda / K_{h}}
$$

where $A_{x}$ and $A_{0}$ are specific activities $\left(\mathrm{Bq} \mathrm{m}^{-3}\right)$ at some $x$ distance offshore $(\mathrm{m})$ and at the shoreline, respectively, and $\lambda$ is the decay coefficient of the radionuclide $\left(\mathrm{d}^{-1}\right)$. Since atmospheric evasion can enhance radon-222 loss across the shelf, non-gaseous tracers are typically used (for exam- 
ple, radium-223 and radium-224) to determine the mixing coefficient and then subsequently applied to radon-222 gradients. However, since the radium isotopes were not measured in this study, the mixing coefficient $\left(K_{h}\right)$ could not be determined in this manner. As an alternative, we used an advection-diffusion equation similar to that presented by Hancock and others (2006):

$$
\frac{d}{d x}\left(K_{h} \frac{d I_{R n}}{d x}\right)-\lambda I_{R n}=-B_{x}
$$

where $B_{x}\left(\mathrm{~Bq} \mathrm{~m}^{-2} \mathrm{~d}^{-1}\right)$ is a benthic source term written as a function of distance offshore. Equation 7 was modified to examine excess inventory as opposed to specific activity. Excess inventory was determined by correcting for atmospheric evasion and water-column production prior to modeling. For this study, $B_{x}$ was written as an exponential function based on trends observed by Smith and Swarzenski (2012):

$$
B_{x}=B_{0} e^{-C x}
$$

where $B_{0}$ is the flux at $x=0\left(\mathrm{~Bq} \mathrm{~m}^{-2} \mathrm{~d}^{-1}\right)$ and $C$ is a decay constant $\left(\mathrm{m}^{-1} \mathrm{or} \mathrm{km}^{-1}\right)$. Equation 7 was solved numerically using a fully implicit, central difference approach. Boundary conditions for equation 7 were chosen as a fixed inventory (Dirichlet type) at the coastal boundary and a no-flux boundary (Neumann type) beyond $80 \mathrm{~km}$ offshore. The first quartile, median, third quartile, and the maximum of the $l n$-transformed nearshore inventories $(<5 \mathrm{~km}$ offshore; $\mathrm{n}=46$ for February 2009 and $n=53$ for August 2009) were used to evaluate dependence on the variance of the nearshore data. The model was optimitized for $K_{h}, B_{0}, C$ using the Nelder-Mead simplex algorithm (Nelder and Mead, 1965; Press, 1992) and a modified $\chi^{2}$ goodness-of-fit parameterization:

$$
\chi^{2}=\sum_{i=1}^{n}\left(\frac{I_{R n_{i}, \text { meas }}-I_{R n_{i}, \text { alc }\left(K_{h}, B_{0}, C\right)}}{\sigma_{R n_{i}, \text { meas }}}\right)+t \sum_{i=1}^{n}\left(\frac{I_{R n_{i}, \text { meas }}-I_{R n_{i}, \text { calc }\left(K_{h}, B_{0}, C\right)}}{\sigma_{R n_{i}, \text { meas }}}\right)
$$

where $I_{R n_{i} \text {,meas }}$ and $I_{R n_{i}, \text { calc }}$ are the measured and calculated radon inventories, respectively; $\sigma_{R n_{i}, \text { meas }}$ is the error in the measured inventory, and $t$ is a weighting factor to ensure fitting parameters are greater than 0 .

\section{Results and Discussion}

\section{Spatial and Temporal Radon Mapping Data}

Total radon-222 activities measured during the February and August 2009 cruises are presented in figure 2. The data show inherently higher radon-222 activities closer to the shoreline and decreasing activities farther offshore. Two general areas that have consistently high radon-222 ac- 


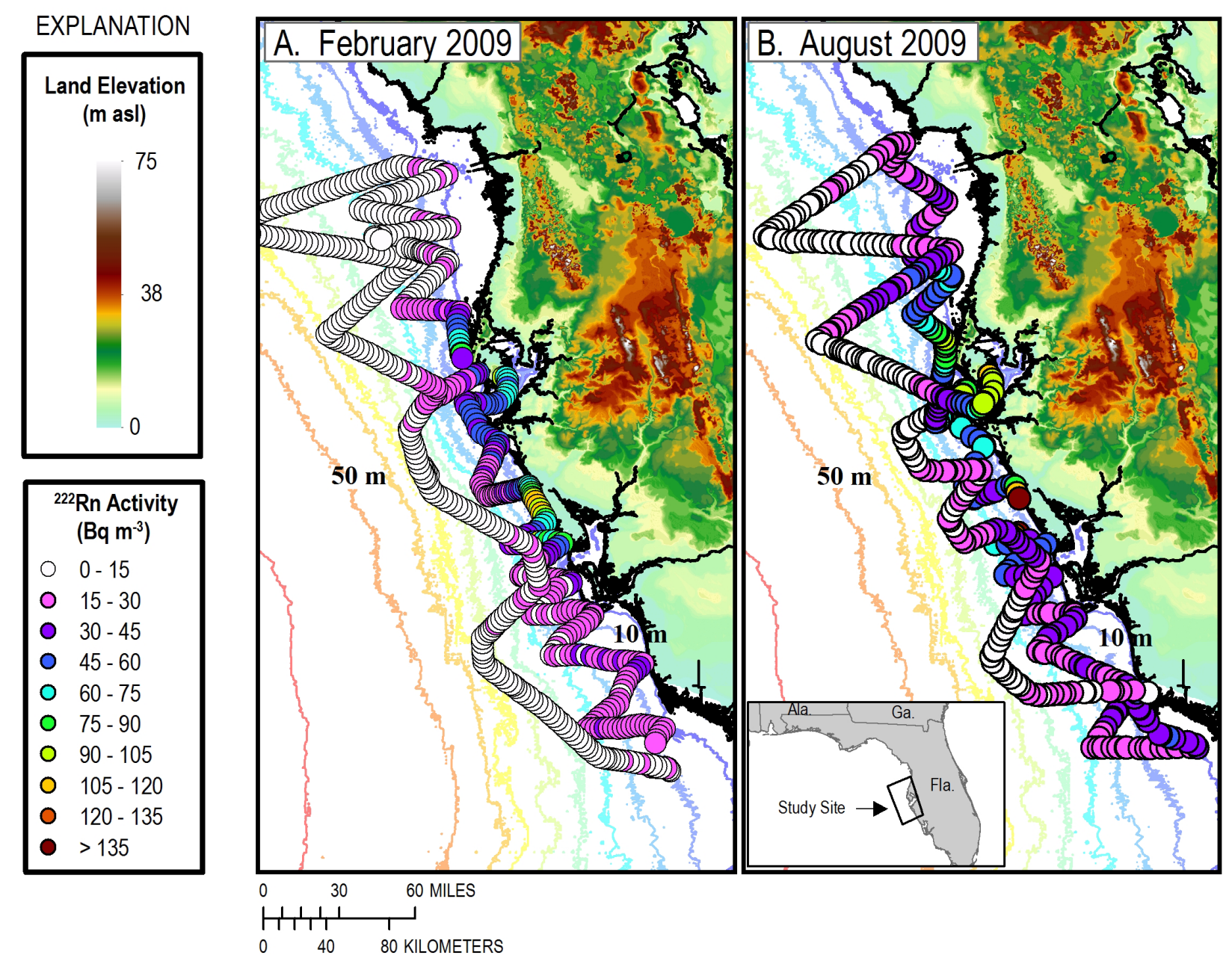

Figure 2. Map showing surface-water radon-222 activity for the (A) February 2009 and (B) August 2009 cruises. Warmer colors on land indicate higher elevations that decrease down-gradient to greenish-blue. Colored lines beyond the shoreline (solid black line) are bathymetry, increasing from blue (shallowest) to red (deepest). Abbreviations: $\mathrm{m}$, meter; $\mathrm{m}$ asl, meters above sea level; $\mathrm{Bq} \mathrm{m}^{-3}$, becquerels per cubic meter.

tivities are offshore Indian Rocks Beach and Venice, Fla. In these regions, radon-222 activities are two times higher than similar shallow-water sections of the survey. Offshore activities are consistently low. The two-dimensional context of the data provides some insight to the regional heterogeneity of surface radon-222 distribution; however, converting the data into one dimensional (that is, a function of distance offshore) provides more generic yet quantitative trends at the entire shelf scale.

During the February 2009 cruise, 662 individual surface-water radon-222 activities were determined with only 6 samples falling below the MDA. Radon-222 activities for the remaining 656 measurements ranged between 3.21 and $120 \mathrm{~Bq} \mathrm{~m}^{-3}$. Activities decrease exponentially with respect to both distance offshore $\left(r^{2}=0.70\right)$ and water depth $\left(r^{2}=0.45\right.$; not shown $)$. In both cases, radon-222 activities merged to an asymptotic activity of $8.0 \pm 3.3 \mathrm{~Bq} \mathrm{~m}^{-3}(\mathrm{n}=209)$, which corresponds to approximately $40 \mathrm{~km}$ offshore or approximately 20 -m water depth (fig. 3 ). Inshore of the 

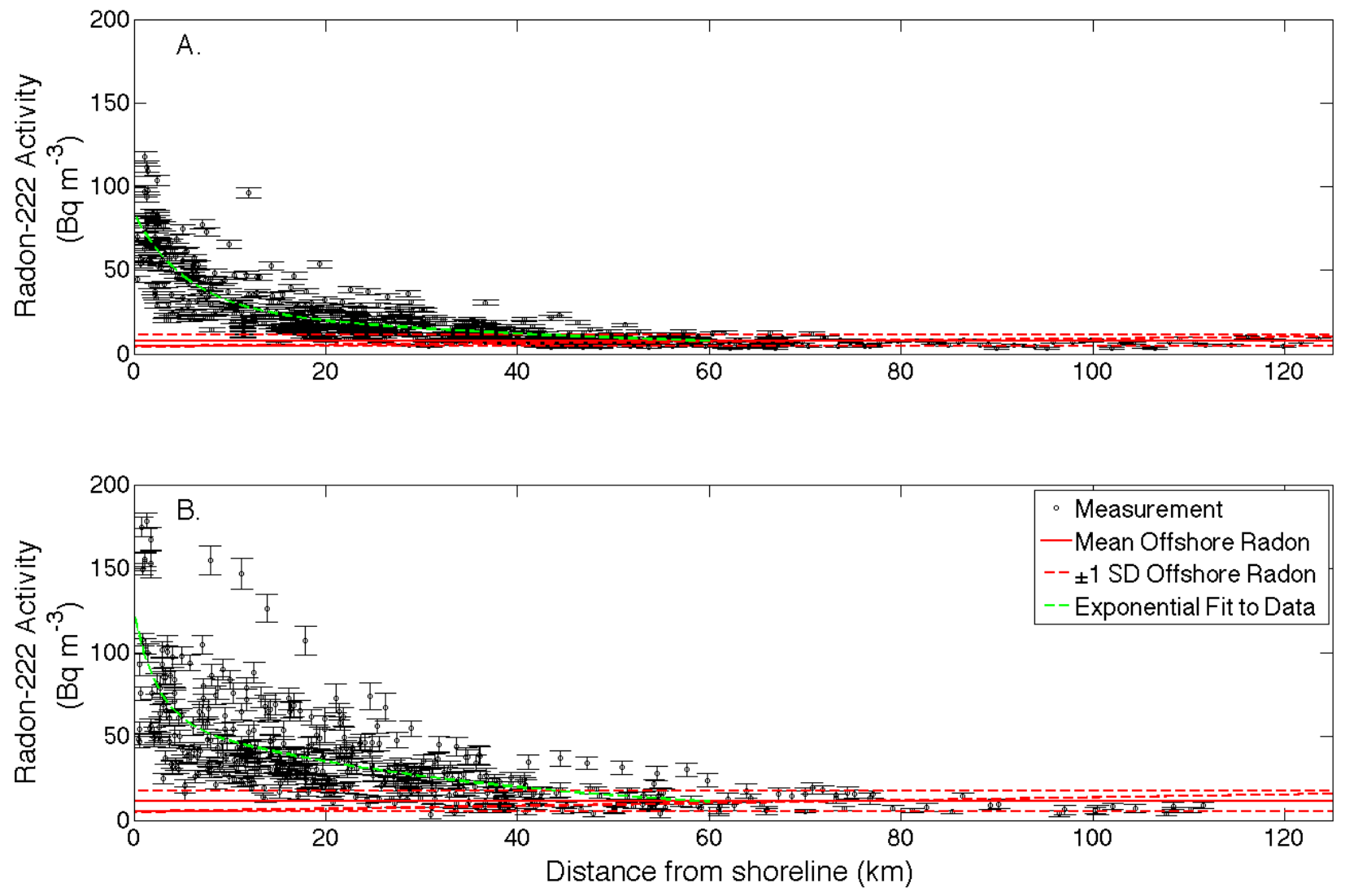

Figure 3. Radon-222 activity plotted as a function of distance from the shoreline for the (A) February 2009 and (B) August 2009 cruises. Solid red line indicates the mean offshore radon-222 activity, which is interpreted as the supported radon-222 in secular equilibrium with radium-226. Dashed red lines are one standard deviation about the mean. Green line is an exponential regression of the data. Abbreviations: $\mathrm{km}$, kilometer; $\mathrm{Bq} \mathrm{m}^{-3}$, becquerels per cubic meter; $\mathrm{SD}$, standard deviation.

$20-\mathrm{m}$ isobath, radon-222 activities were more variable, having a range of 4.34 to $117 \mathrm{~Bq} \mathrm{~m}^{-3}$, with approximately 96 percent of the nearshore data greater than the offshore mean radon activity.

During the August 2009 cruise, 454 measurements of individual surface water radon-222 activities were determined with only 5 samples falling below the MDA. Radon-222 activities for the remaining 449 measurements ranged between 3.50 and $178 \mathrm{~Bq} \mathrm{~m}^{-3}$. Radon-222 activities decrease offshore; however, regression with distance $\left(r^{2}=0.45\right)$ and water depth $\left(r^{2}=0.25\right.$; not shown) are less robust than during the February cruise (fig. 3). Offshore radon-222 activities merge at approximately $40 \mathrm{~km}$ offshore or approximately $20-\mathrm{m}$ water depth. The asymptotic radon-222 activity is $11.5 \pm 6.0 \mathrm{~Bq} \mathrm{~m}^{-3}(\mathrm{n}=70)$. Nearshore data (that is, inshore of the $20-\mathrm{m}$ isobath) range from 4.17 to $178 \mathrm{~Bq} \mathrm{~m}^{-3}$, with approximately 88 percent of the nearshore data greater than the offshore mean radon activity.

Time-series wind-velocity data from two offshore buoys are presented in figure 4. In general, the winds were on average slightly calmer during the August $\left(2.79 \mathrm{~m} \mathrm{~s}^{-1}\right)$ cruise than during the 
February cruise $\left(3.22 \mathrm{~m} \mathrm{~s}^{-1}\right)$. However, temporal variation (range) during each sampling trip was quite large, with higher wind velocities observed during the first day of each cruise and slowly dying down thereafter. The wind velocities observed at two buoys during each cruise were regionally coherent, with only slight differences in the overall wind velocity at any point in time between the two buoys (fig. 4).
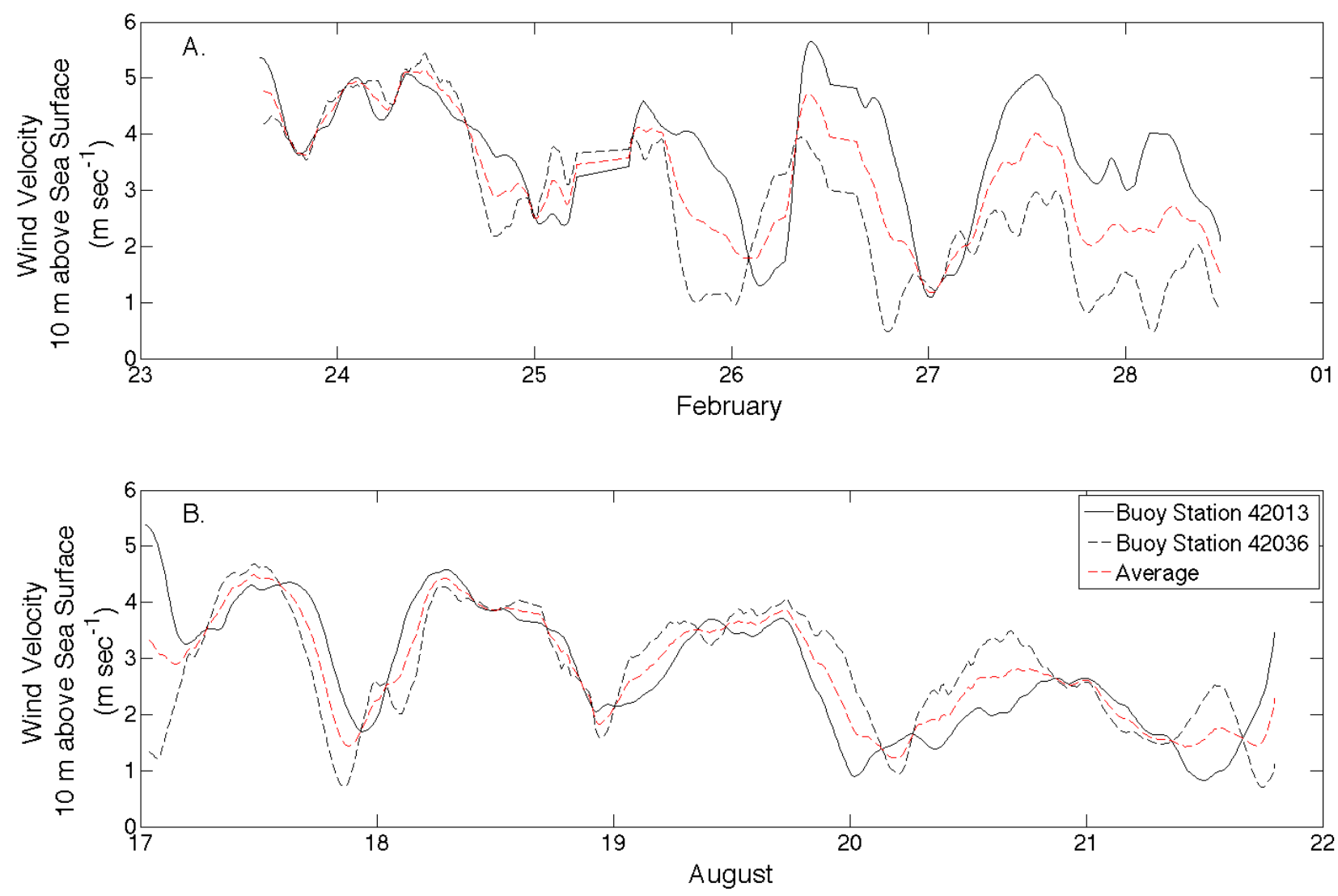

Figure 4. Wind speed normalized to $10 \mathrm{~m}$ above sea level from the NOAA Buoys 42036 (northern) and 42013 (southern) for the (A) February 2009 and (B) August 2009 cruises. Abbreviations: m, meter; $\mathrm{m} \mathrm{s}^{-1}$, meters per second.

\section{Radon-222 Production and Decay}

Estimates of radon-222 production from the natural decay of radium-226 at the shelf scale were made through careful examination of total radon-222 data. Previous investigations (Fanning and others, 1981, 1982; Smith and Swarzenski, 2012) along the WFS have found relatively constant radium-226 values at least at the shelf scale. Fanning and others (1982) found that cross-shelf distribution of radium-226 was fairly uniform $\left(9.67 \pm 4.67 \mathrm{~Bq} \mathrm{~m}^{-3} ; \mathrm{n}=12\right)$ in the surface mixed layer between Tampa Bay and Charlotte Harbor, Fla. Smith and Swarzenski (2012) observed similar activities $\left(6.33 \pm 3.00 \mathrm{~Bq} \mathrm{~m}^{-3} ; \mathrm{n}=10\right)$ along the inner WFS north of Tampa Bay. Considering the extent of this study, we felt it reasonable to assume that the radium-226 activity of the surface water was spatially homogeneous. Building from this assumption, total radon-222 values beyond approx- 
imately 40 to $60 \mathrm{~km}$ (20-m isobath) were fairly constant. In fact, average total radon-222 measured beyond $40 \mathrm{~km}$ during the February and August 2009 cruises were $8.00 \pm 3.33 \mathrm{~Bq} \mathrm{~m}^{-3}$ and $11.5 \pm 6.0$ $\mathrm{Bq} \mathrm{m}^{-3}$, respectively, and were within the same range as previously published radium-226 activities. Hence, it seemed reasonable to interpret these asymptote total radon-222 activities as the marine background and sourced solely by the decay of dissolved radium-226 in the water column. By assuming secular equilibrium with radon-222 and radium-226 across the shelf, radon-222 production rates were computed as $\lambda_{R n} A_{R a}$. Thus, the shelf-wide production rates of radon-222 for February and August were $1.45 \pm 0.60 \mathrm{~Bq} \mathrm{~m}^{-3} \mathrm{~d}^{-1}$ and $2.09 \pm 1.09 \mathrm{~Bq} \mathrm{~m}^{-3} \mathrm{~d}^{-1}$, respectively.

Radon loss (decay flux) in the water column due to radioactive decay was determined using $\lambda_{R n} A_{R n}$. Since the fluxes are linearly related to the specific activity, the same two- and one-dimensional patterns were observed in the data. During the February cruise, radon decay flux ranged between 0.58 and $21.3 \mathrm{~Bq} \mathrm{~m}^{-3} \mathrm{~d}^{-1}$, with a mean flux of $3.90 \pm 3.58 \mathrm{~Bq} \mathrm{~m}^{-3} \mathrm{~d}^{-1}$. Like specific activity during the August cruise, average radon decay flux was higher $\left(6.59 \pm 5.28 \mathrm{~Bq} \mathrm{~m}^{-3} \mathrm{~d}^{-1}\right)$ than during February but with a similar range (0.63 to $\left.32.29 \mathrm{~Bq} \mathrm{~m}^{-3} \mathrm{~d}^{-1}\right)$.

As shown in equation 1, production and decay fluxes must be integrated over the thickness of the mixed layer / water column in order to compare with other sources (benthic fluxes, mixing) and sinks (mixing, atmospheric evasion). Unfortunately, vertical hydrographic profiles of salinity, temperature, and depth were not performed on either of the cruises. However, the decrease of radon-222 activities to near-shelf background activities at approximately the $20-\mathrm{m}$ isobath provides an interesting observation. In general, stratification along the WFS is quite variable throughout the year (Morey and O'Brien, 2002). During winter months, warmer Gulf of Mexico and cooler shelf waters mix relatively isotropically across the shelf, with horizontal stratification occurring out to the shelf - slope break. During the summer months, increased heat flux and relaxed local wind forcing create a vertical stratification across much of the shelf and slope system. However, vertical summer- and winter-density gradients within the 20-m isobath are less defined than for the rest of the WFS. Water-column profile data collected as part of the National Oceanic and Atmospheric Administration (NOAA)-funded study (that is, Ecology and Oceanography of Harmful Algal Blooms or ECOHAB:WFS) show nearly horizontal thermal and salinity gradients inshore of the 20-m isobath for both the summer and winter seasons (Liu and Weisberg, 2007). Based on this observation, we computed an initial radon-222 water-column inventory by assuming radon is evenly distributed throughout the entire water column inshore the 20-m isobath. Smith and Swarzenski (2012) showed this assumption is fairly reasonable between the 5- and 20-m isobath. When water depths exceed $20 \mathrm{~m}$, we assume a 20-m-thick mixed upper water column. Moore and Shaw (2008) made similar observations and assumptions for the Atlantic Ocean offshore from Georgia and Florida. 


\section{Radon-222 Evasion}

Atmospheric fluxes were computed using equation 2 and the assumption that the atmospheric radon concentration was negligible. To test the validity of this assumption, we compared the atmospheric fluxes for the February cruise assuming radon-in-air concentrations of 0.00 and 10 $\mathrm{Bq} \mathrm{m}^{-3}$ air (or 0.00 and $2.67 \mathrm{~Bq} \mathrm{~m}^{-3}$ water at $25^{\circ} \mathrm{C}$, respectively). Regression analysis between the two datasets indicated a nearly 1:1 relationship and a regression coefficient of 1 (fig. 5).

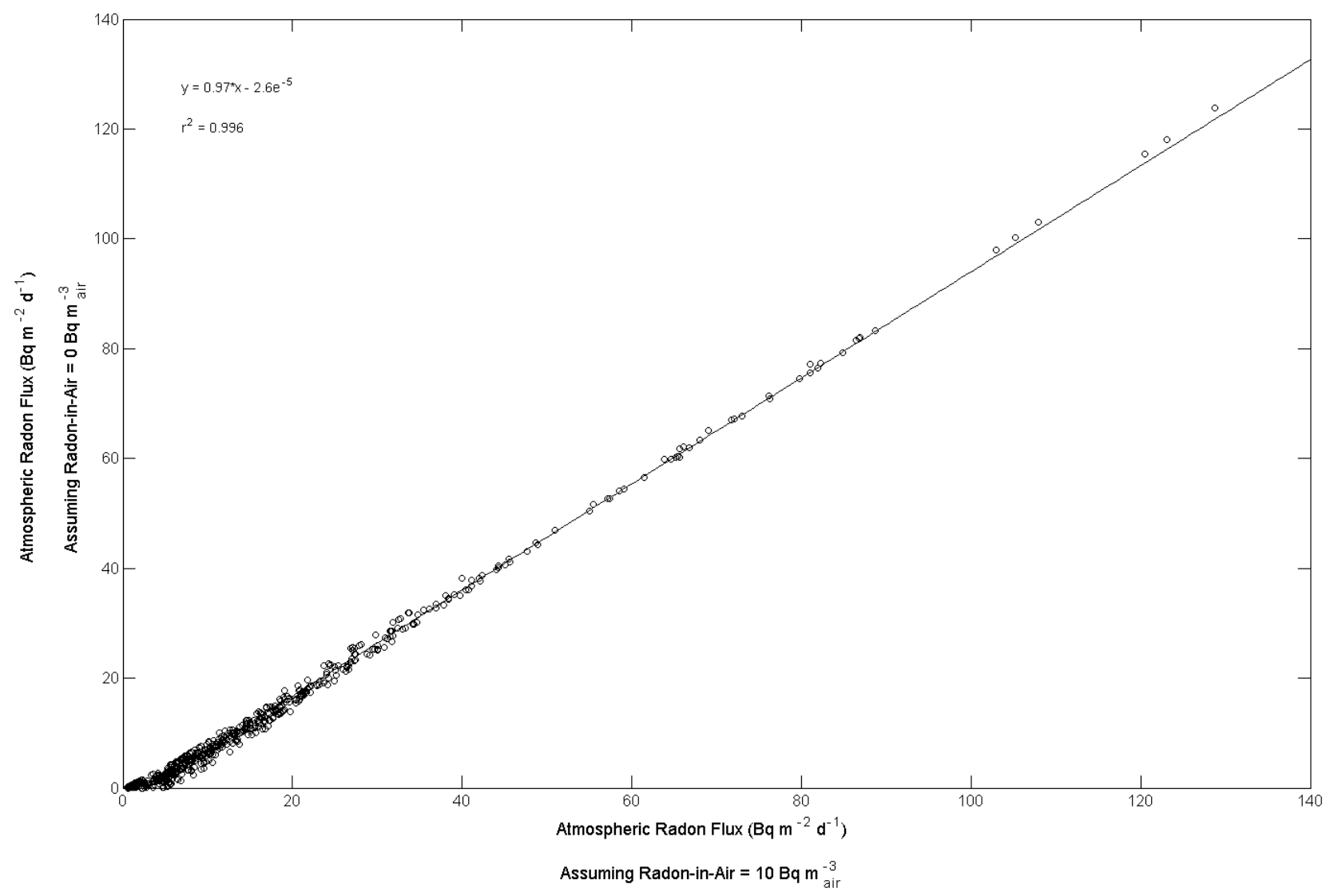

Figure 5. Regression analysis of atmospheric evasion rates of radon-222 assuming atmospheric radon-222 activity of 0

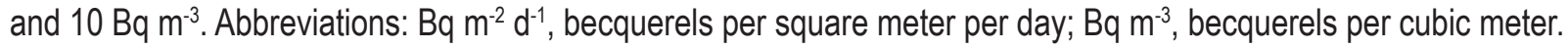

Similarly, the average absolute difference between these datasets is $0.0019 \mathrm{~Bq} \mathrm{~m}^{-2} \mathrm{~d}^{-1}$, which is six orders of magnitude less than the average atmospheric flux $\left(16.7 \mathrm{~Bq} \mathrm{~m}^{-2} \mathrm{~d}^{-1}\right)$ and two orders of magnitude less than the minimum atmospheric flux $\left(0.55 \mathrm{~Bq} \mathrm{~m}^{-2} \mathrm{~d}^{-1}\right)$. Thus, for a background atmospheric concentration exceeding the average coastal ocean value of $17 \mathrm{~Bq} \mathrm{~m}^{-3}$ air, the use of equation 2 holds.

The atmospheric fluxes for the February and August cruises are presented in figures 6 and 7. Atmospheric fluxes varied by approximately four orders of magnitude during both cruises $(0.45$ to $202 \mathrm{~Bq} \mathrm{~m}^{-2} \mathrm{~d}^{-1}$ ) with slightly higher individual fluxes during August (maximum $=202 \mathrm{~Bq} \mathrm{~m}^{-2} \mathrm{~d}^{-1}$ ) 


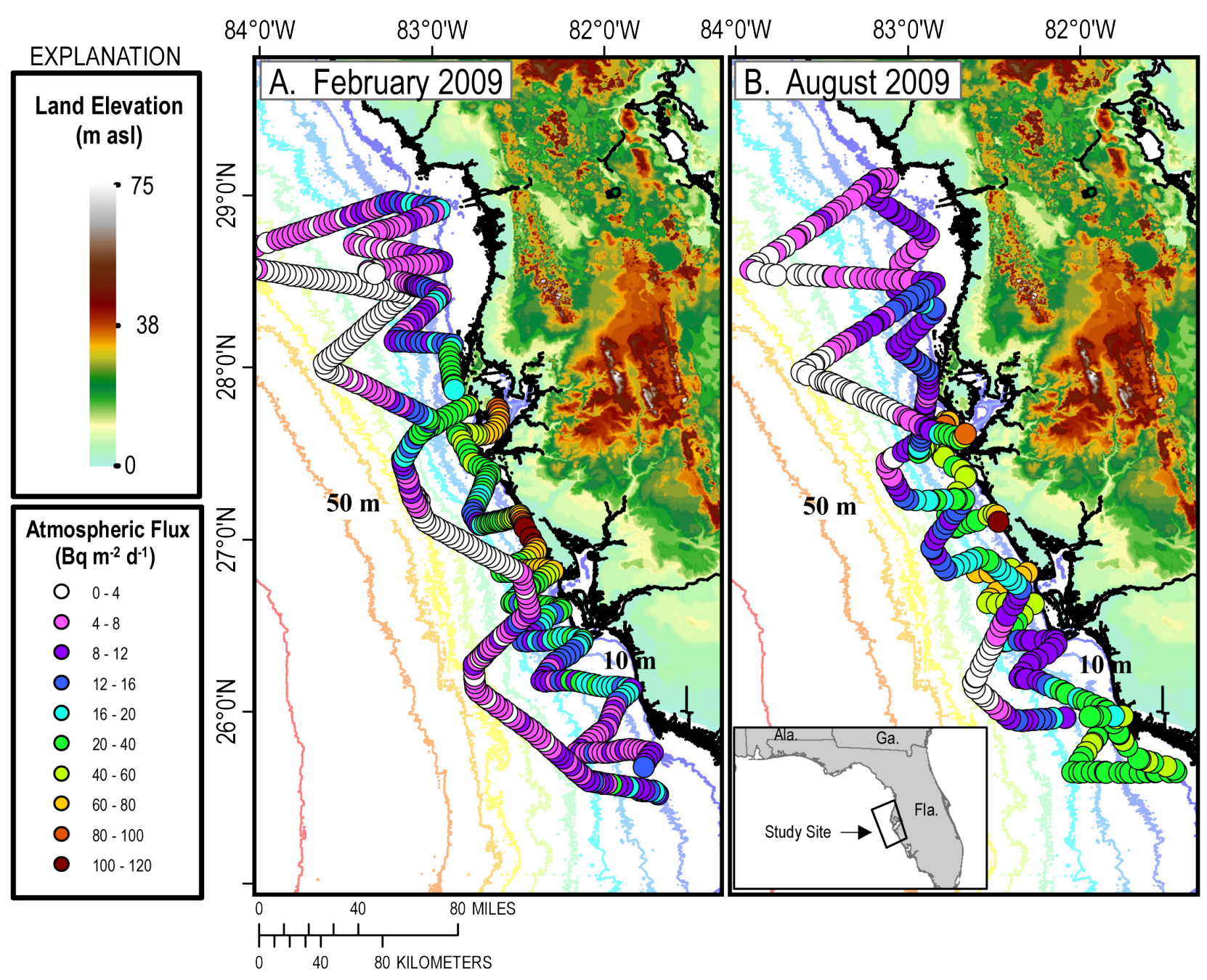

Figure 6. Map showing atmospheric radon-222 flux for the (A) February 2009 and (B) August 2009 cruises. Warmer colors on land indicate higher elevations that decrease down-gradient to greenish-blue. Colored lines beyond the shoreline (solid black line) are bathymetry, increasing from blue (shallowest) to red (deepest). Abbreviations: $m$, meter; $m$ asl, meters above sea level; Bq m${ }^{-2} \mathrm{~d}^{-1}$, becquerels per square meter per day.

relative to February (maximum $=128 \mathrm{~Bq} \mathrm{~m}^{-2} \mathrm{~d}^{-1}$ ). The mean flux and overall variability were both higher during August $\left(26.3 \pm 35.0 \mathrm{~Bq} \mathrm{~m}^{-2} \mathrm{~d}^{-1}\right)$ compared with February $\left(16.7 \pm 19.5 \mathrm{~Bq} \mathrm{~m}^{-2} \mathrm{~d}^{-1}\right)$ despite slightly higher wind velocities in February. This reflects the linear dependence of equations 2 and 3 on the surface-water concentration, which on average was higher during the August cruise.

\section{Radon-222 Cross-Shelf Mixing}

Evasion-corrected excess radon-222 inventories (hereafter, just "inventories") and model results are presented in figure 8 . Much like radon-222 activity, inventories computed from direct measurements were highest near the shoreline and decreased offshore. Inventories for February 2009 were between 58.7 and $1,820 \mathrm{~Bq} \mathrm{~m}^{-2}$ with a mean of $363 \pm 257 \mathrm{~Bq} \mathrm{~m}^{-2}$. August 2009 inventories were slightly higher and were between 67.4 and 2,980 $\mathrm{Bq} \mathrm{m}^{-2}$ with a mean of $574 \pm 460$ 

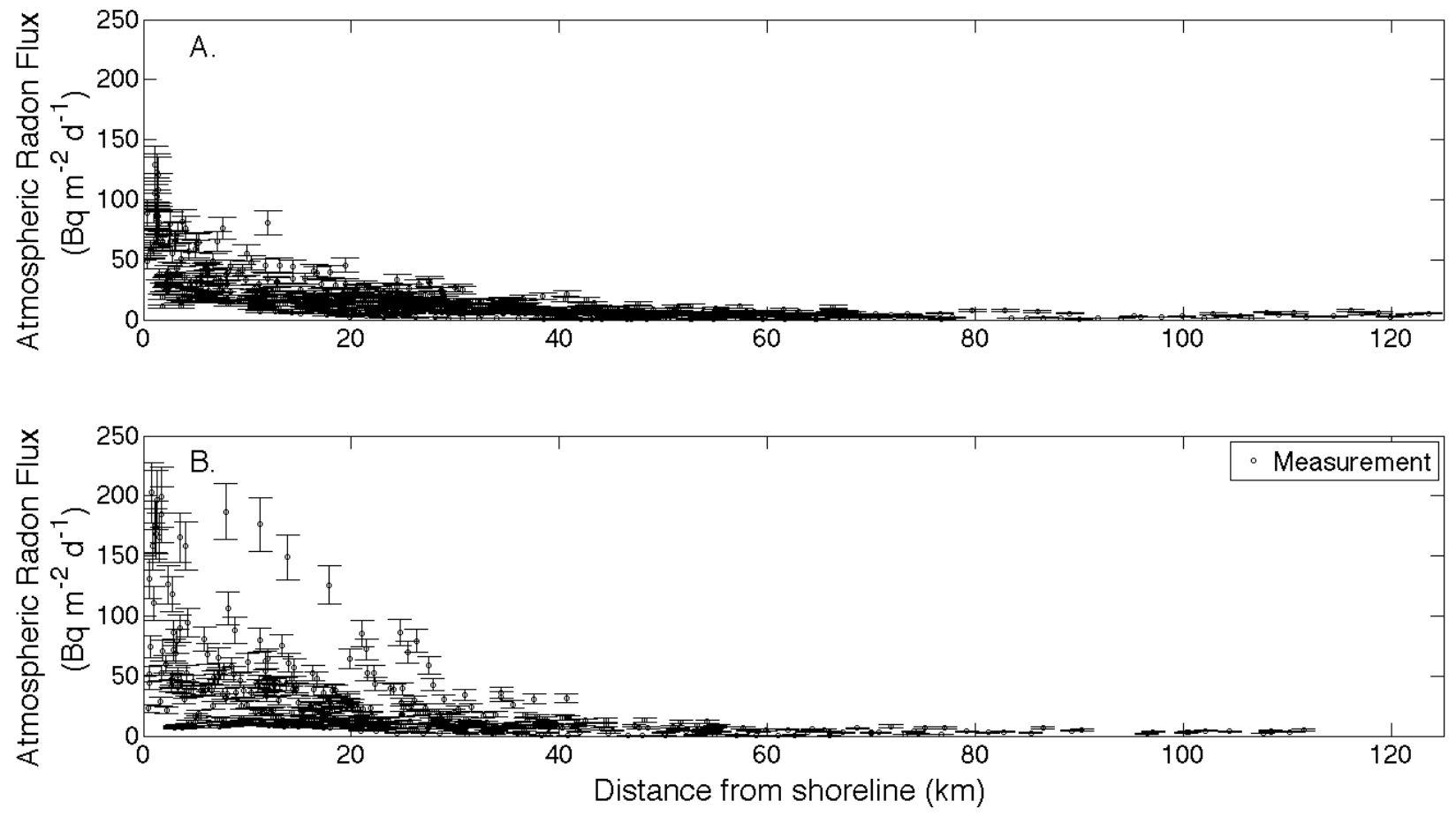

Figure 7. Atmospheric radon-222 flux plotted as a function of distance from the shoreline for the (A) February 2009 and (B) August 2009 cruises. Abbreviations: $\mathrm{km}$, kilometer; Bq $\mathrm{m}^{-2} \mathrm{~d}^{-1}$, becquerels per square meter per day.

$\mathrm{Bq} \mathrm{m} \mathrm{m}^{-2}$

The boundary conditions set by the first quartile, median, third quartile, and maximum inventory for the nearshore data are presented in table 1 for both seasons along with optimized values of $K_{h}, B_{0}, C$. Mixing coefficients $\left(K_{h}\right)$ derived from the radon-222 data varied by almost three orders of magnitude $\left(10^{-0.38}-10^{3.4} \mathrm{~km}^{2} \mathrm{~d}^{-1}\right)$. For the median coastal boundary condition scenarios, the mixing coefficients were $10^{1.8}$ and $10^{0.7} \mathrm{~km}^{2} \mathrm{~d}^{-1}$ for the February and August cruises, respectively. The mixing coefficients have a negative correlation with both the coastal boundary condition and benthic radon-222 flux at the shoreline.

Despite the seemingly large variation in the mixing coefficients, the range and average of these values compare well with the range and average mixing coefficients obtained by radium-223 and radium-224 (Smith and others, 2011). Based on 13 independent studies using short-lived radium isotopes, mixing coefficients generally range from $10^{-2}$ to $10^{3.7} \mathrm{~km}^{2} \mathrm{~d}^{-1}$ (Smith and others, 2011). More locally, Smith and Swarzenski (2012) reported radium-based mixing coefficients of $10^{1.2}$ to $10^{1.9} \mathrm{~km}^{2} \mathrm{~d}^{-1}$ for the coastal region (within $15 \mathrm{~km}$ of the shoreline) offshore from Pinellas County, Fla., which lies in the domain of our larger-scale study. Although radon and radium are geochemically different, correcting radon-222 inventories for evasion normalizes the two elements to similar (assumed) conservative geochemical behavior. Also, since short-lived radium isotopes (radium-223 


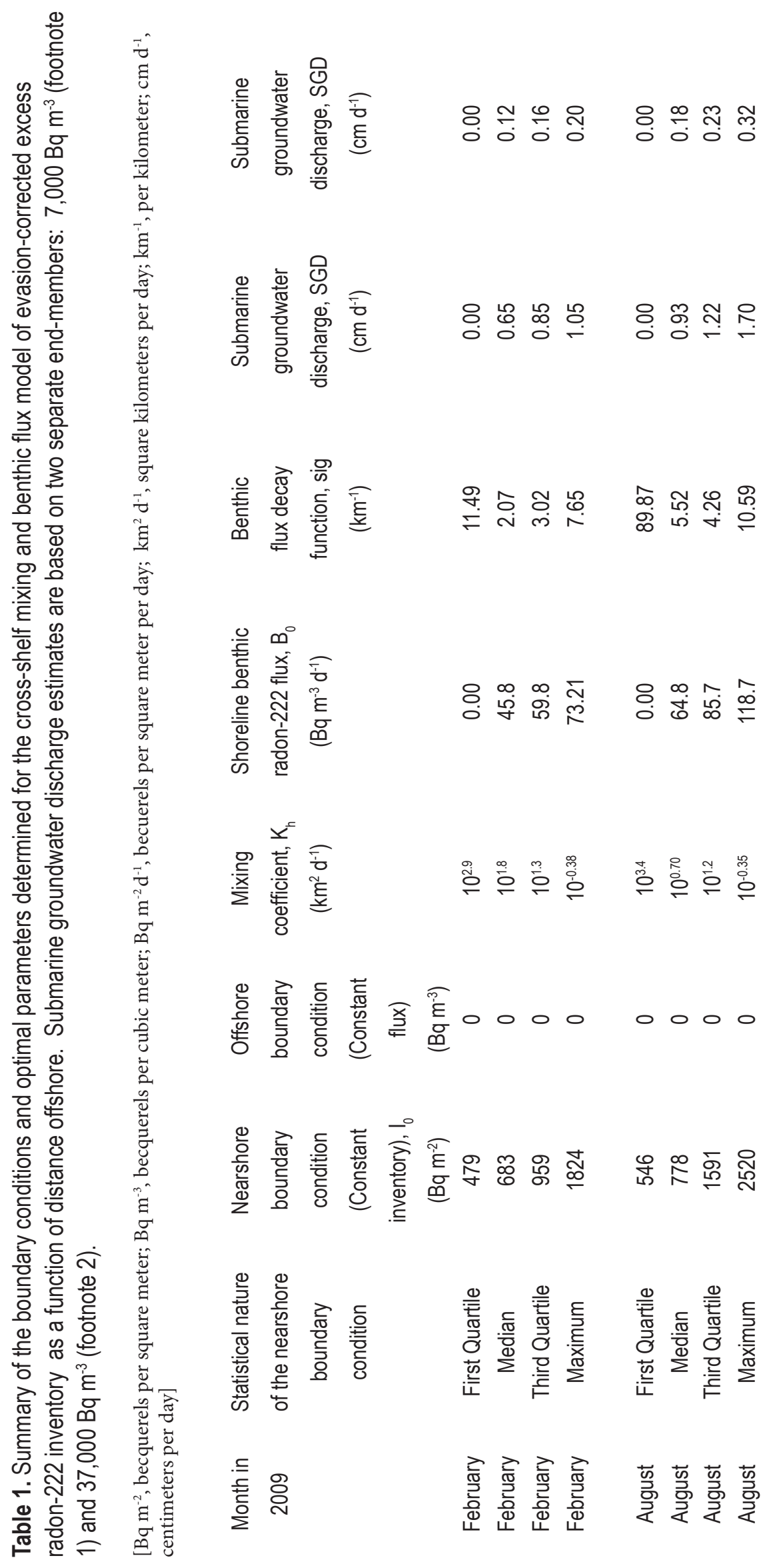


and radium-224) have a similar decay rate $\left(\lambda_{223}\right.$ is $0.0582 \mathrm{~d}^{-1}$ and $\lambda_{224}$ is $\left.0.190 \mathrm{~d}^{-1}\right)$ to radon-222 $\left(\lambda_{222}\right.$ is $\left.0.181 \mathrm{~d}^{-1}\right)$, we feel the comparison to be quite reasonable.

\section{Radon-222 Benthic Fluxes}

Optimized values of the benthic radon-222 flux $\left(B_{0}\right)$ at the shoreline were between 0.00 $\left(\sim 10^{-5}\right)$ and $118 \mathrm{~Bq} \mathrm{~m}^{-2} \mathrm{~d}^{-1}$ for the two trips. The median cases for February and August cruises were 45.8 and $64.8 \mathrm{~Bq} \mathrm{~m}^{-2} \mathrm{~d}^{-1}$, respectively. While benthic radon-222 fluxes increased log-linear $\left(r^{2}=0.85\right)$ with the nearshore boundary condition, the overall variability (excluding the first quartile) was fairly low (average $(\mathrm{SD})=74.7(25.4) \mathrm{Bq} \mathrm{m}^{-2} \mathrm{~d}^{-1}$ ). The benthic flux decay function coefficient $(C$ ) values were quite variable, with a range of over an order of magnitude for both seasons $\left(2.07\right.$ and $\left.89.87 \mathrm{~km}^{-1}\right)$. There was no apparent relationship between the decay term $(C)$ and the boundary conditions or the other parameters. The large decay coefficients indicated rapid decay of benthic radon-222 fluxes across the shelf.

The benthic radon-222 fluxes $\left(74.7 \pm 25.4 \mathrm{~Bq} \mathrm{~m}^{-2} \mathrm{~d}^{-1}\right)$ obtained from the model are at the low end of previously reported fluxes for the eastern and northeastern Gulf of Mexico (0.00 to 3,330 Bq m${ }^{-2} \mathrm{~d}^{-1}$; table 2; compare with Cable and others, 1996b). Differences in scale (spatial) of observation and the framework (hydrogeologic) best explain these "lower" estimates. For example, high benthic radon-222 fluxes tend to be focused at sites proximal to the shoreline, whereas studies focused farther offshore have generally lower fluxes. This fits reasonably well with previous models for SGD - assuming that SGD is the dominant process driving radon-222 flux - where SGD rates decay rapidly offshore (Bokuniewicz, 1992). Furthermore, our study integrates over large spatial scales and reduces the ability to resolve true nearshore fluxes. Although the model indicates benthic radon-222 fluxes at the "shoreline" $(\mathrm{x}=0)$, our estimates pertain to fluxes as much as $5 \mathrm{~km}$ from the shoreline. While ideally at a small scale, refinement of fluxes in nearshore studies would be on the order of tens of meters; however, when the study area is almost $50,000 \mathrm{~km}^{2}$, then the need to refine to a $5-\mathrm{km}$ resolution is adequate and substantial.

Also contributing variability of our large-scale estimates to other synoptic studies are hydrogeologic controls. Smith and Swarzenski (2012) data originate from an area where the adjacent onshore topographic gradient is large, the Floridan aquifer is very near the seafloor, and potential outwelling of groundwater to the coastal zone is high. Similarly, the high benthic fluxes Santos and others (2009) observed correspond to a region in the northeastern Gulf of Mexico where significant fresh groundwater discharge influences the coastal zone. In contrast, the bulk of the measurements obtained as part of this study were focused between Tampa Bay and Charlotte Harbor, Fla., in a region where the Floridan aquifer is much more deeply confined and topographic gradients are generally small. 

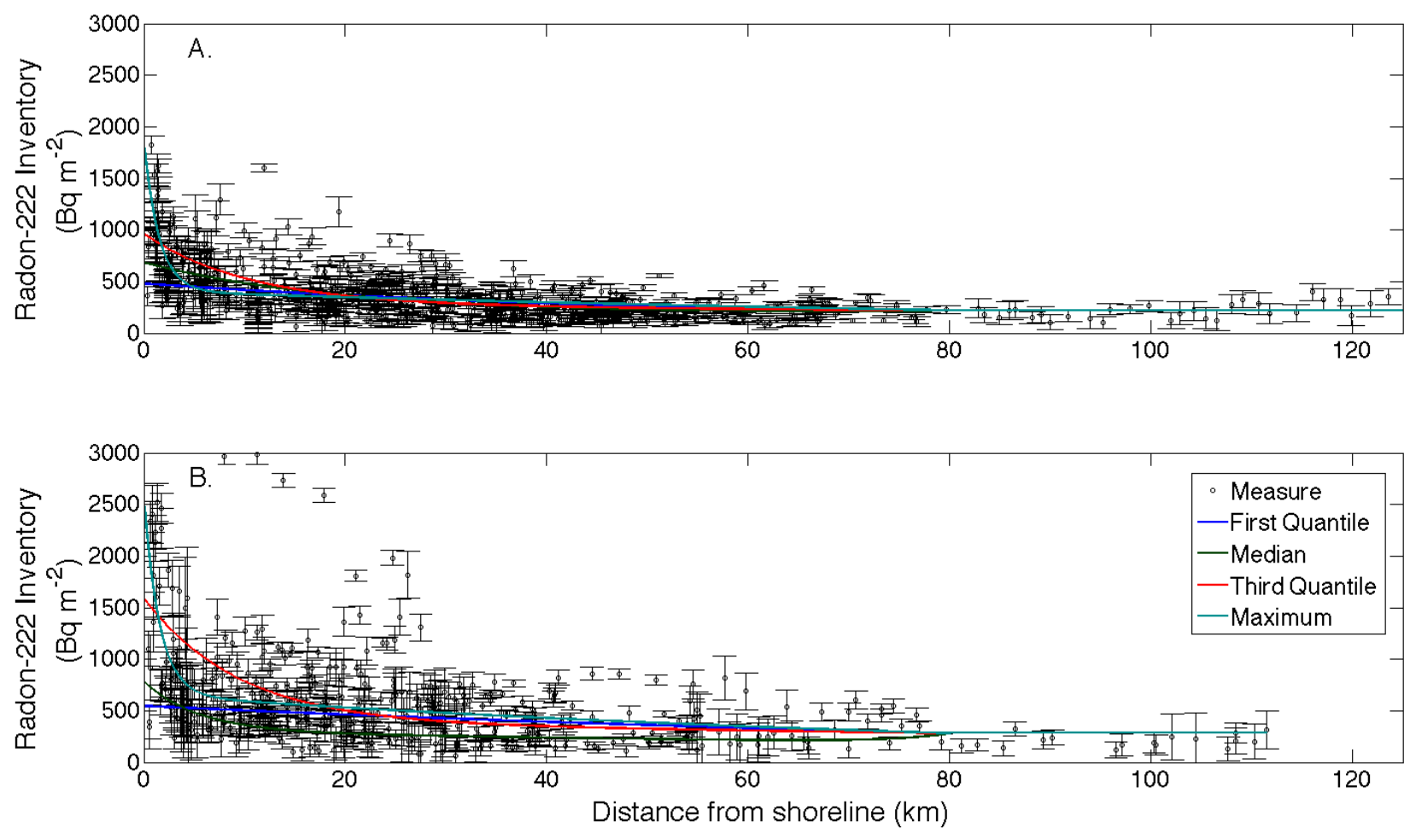

Figure 8. Evasion-corrected excess radon-222 inventories plotted as a function of distance from the shoreline for the (A) February 2009 and (B) August 2009 cruises. Colored lines show modeled data fit for the scenario where the inshore boundary condition is the first quartile (blue), median (green), third quartile (red), or maximum (cyan) of the radon-222 inventories within $5 \mathrm{~km}$ of the shoreline. Abbreviations: $\mathrm{km}$, kilometer; $\mathrm{Bq} \mathrm{m}^{-2}$, becquerels per square meter.

In small-scale studies, conversion of benthic radon-222 fluxes to SGD is relatively straightforward, as the relationship between the two is linear. Groundwater radon-222 end-members used to convert the fluxes to fluid rates are often derived from equilibration studies or regional groundwater radon-222 activities. Only a few studies have investigated radon-222 activities in either deep submarine groundwater or shallow-marine pore waters. In submarine spring fluids discharging to the WFS off the Charlotte Harbor region, Fanning and others (1981) reported radon-222 activities on the order of $14,300 \pm 2,000 \mathrm{~Bq} \mathrm{~m}^{-3}$. Radon-222 activities were enriched almost an order of magnitude over dissolved radium-226 $\left(1,550 \pm 330 \mathrm{~Bq} \mathrm{~m}^{-3}\right)$ in the submarine spring groundwater and almost six orders of magnitude greater than offshore Gulf of Mexico seawater $(10 \pm 15 \mathrm{~Bq}$ $\left.\mathrm{m}^{-3}\right)$. Offshore from Indian Rocks Beach, shallow porewater radon-222 $\left(7,340 \pm 1,400 \mathrm{~Bq} \mathrm{~m}^{-3}\right)$ is similarly enriched relative to the overlying surface water $\left(94 \pm 38 \mathrm{~Bq} \mathrm{~m}^{-3}\right.$; Smith and Swarzenski, 2012). At the same location, marine groundwater collected from 1.5 to $3.5 \mathrm{~m}$ below the seafloor had radon-222 an order of magnitude greater $\left(31,600 \pm 8,200 \mathrm{~Bq} \mathrm{~m}^{-3}\right.$; Smith and Swarzenski, 2012) than the pore waters and about twice that of spring water observed to the south. In comparison, radon-222 values from water-supply wells on land adjacent to the surveys average $37,000 \mathrm{~Bq} \mathrm{~m}^{-3}$ (FDEP, 2000). While there is no reason to think that radon-222 activities should be constant across the region, it is quite impressive that radon-222 activities among terrestrial groundwater, deep-marine groundwater, and shallow pore water vary by a factor of only five over such a large geographic 


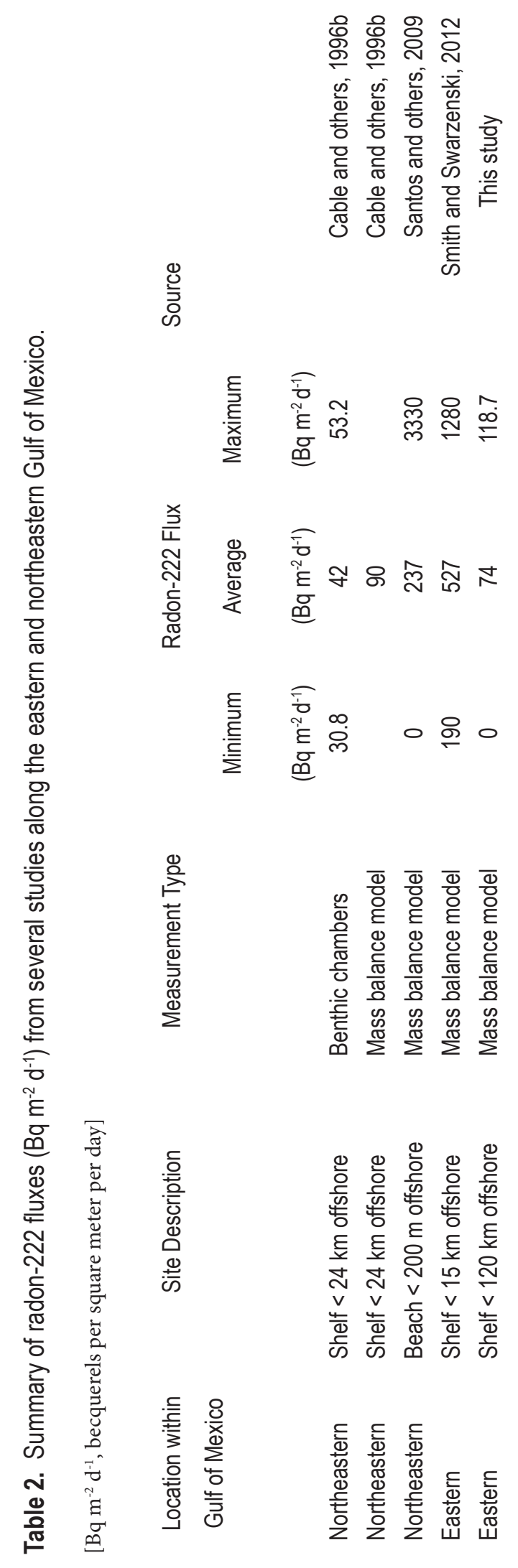


and geologic region. Since the measurements were conducted independently over a time period of almost three decades, it is unlikely that chance would account for this small variability (table 2). In other words, it seems reasonable that given long enough residence time in the aquifer, the radon-222 will reach a secular equilibrium activity between 7,000 and $37,000 \mathrm{~Bq} \mathrm{~m}^{-3}$, and will more likely approach $37,000 \mathrm{~Bq} \mathrm{~m}^{-3}$. Using this range in potential radon-222 sources, the regionally averaged SGD rates would be between 0.12 and $1.70 \mathrm{~cm} \mathrm{~d}^{-1}$, depending on the radon-222 end-member used (table 1).

The approach of addressing SGD from regional radon-222 measurements is simplistic and averages over a number of different spatial (thousands of square kilometers) and temporal (days to seasons) scales. However, the results are interesting in the sense that the estimates of groundwater discharge at the shoreline for this regional shelf scale are comparable (within an order of magnitude) to synoptic studies carried out over various spatial and temporal scales. For example, seepagemeter measurements along the northeastern Gulf of Mexico by Cable and others (1996b) showed an average advection rate of $1.21 \pm 0.49 \mathrm{~cm} \mathrm{~d}^{-1}$ at a distance of $24 \mathrm{~km}$ from the shoreline. Smith and Swarzenski (2012) found that within a region of the cruise domain that SGD rates declined from 15.6 to $0.7 \mathrm{~cm} \mathrm{~d}^{-1}$ from the shoreline to $15 \mathrm{~km}$ offshore. As with these fluxes, given the proposed resolution of the radon-222 measurement $(1-3 \mathrm{~km})$ and the lumping of radon-222 activities within $5 \mathrm{~km}$ of the shoreline, the data are consistent.

\section{Summary}

Radon-222 data collected as part of two shelf-wide cruises provide insight to the large-scale spatial distribution of a commonly used groundwater and oceanographic tracer along the WFS. Using a number of physically reasonable assumptions, the large datasets can be reduced to a more simplistic one-dimensional cross-shelf (that is, distance from shoreline) dataset that can be used to evaluate marine background radon-222 activities, atmospheric fluxes, and decay fluxes. Coupling the reduced spatial data with a physical-based offshore mixing model provided insight to the mechanism, timing, and intensity of both cross-shelf mixing of radon-222 and the benthic supply of radon-222, predominantly at the shoreline. The optimization parameters obtained from the model for mixing and benthic inputs made physical sense, because the model appeared to be less sensitive to benthic radon-222 flux than it did to mixing. The three orders of magnitude variability in the mixing coefficient, while consistent with global and even local observations, is reflected in the nearshore radon-222 gradient. Further work is required to provide reasonable brackets of certainty and confidence on the various modeled parameters and their physical relationships. Refined studies at local scales, such as those presented by Smith and Swarzenski (2012), provide the means to corroborate a large-scale dataset such as this and to aid in scaling between these types of studies. 


\section{Acknowledgments}

We especially thank Jonathan B. Martin of the University of Florida in Gainesville for access to the radon-in-air monitoring devices used during the cruises. We thank Paul Knorr, Sherwood Liu, Mark Hansen, Gary Hill, and Captain Mike Lawrence for their assistance during the cruise. This cruise was funded by the U.S. Geological Survey Coastal and Marine Geology Program, and data analysis and interpretation were part of a U.S. Geological Survey Mendenhall Research Fellowship Program awarded to Christopher G. Smith.

\section{References Cited}

Bertin, C., and Bourg, C.M., 1994, Radon-222 and chloride as natural tracers of the infiltration of river water into an alluvial aquifer in which there is significant river/groundwater mixing: Environmental Science \& Technology, v. 28, p. 794-798.

Bokuniewicz, H., 1992, Analytical descriptions of subaqueous groundwater seepage: Estuaries, v. 15, no. 4, p. 458-464.

Broecker, W.S., Li, Y.H., and Cromwell, J., 1967, Radium-226 and Radon-222: Concentration in Atlantic and Pacific Oceans: Science, v. 158, no. 3806, p. 1307-1310.

Broecker, W.S., and Peng, T.H., 1971, Vertical distribution of radon in Bomex area: Earth and Planetary Science Letters, v. 11 , no. 2, p. 99-108.

Burnett, W.C., Bokuniewicz, H., Huettel, M., Moore, W.S., and Taniguchi, M., 2003, Groundwater and pore water inputs to the coastal zone: Biogeochemistry, v. 66, no. 1-2, p. 3-33.

Burnett, W.C., and Dulaiova, H., 2003, Estimating the dynamics of groundwater input into the coastal zone via continuous radon-222 measurements: Journal of Environmental Radioactivity, v. 69, no. 1-2, p. 21-35.

Burnett, W.C., Santos, I.R., Weinstein, Y., Swarzenski, P.W., and Herut, B., 2007, Remaining uncertainties in the use of Rn-222 as a quantitative tracer of submarine groundwater discharge, in A new focus on groundwater-seawater interactions: Perugia, IAHS Publication, p. 125-133.

Cable, J.E., Bugna, G.C., Burnett, W.C., and Chanton, J.P., 1996a, Application of Rn-222 and $\mathrm{CH}_{4}$ for assessment of groundwater discharge to the coastal ocean: Limnology and Oceanography, v. 41, no. 6, p. 1347-1353.

Cable, J.E., Burnett, W.C., Chanton, J.P., and Weatherly, G.L., 1996b, Estimating groundwater discharge into the northeastern Gulf of Mexico using Radon-222: Earth and Planetary Science Letters, v. 144, p. 591-604.

Clements, W.E., and Wilkening, M.H., 1974, Atmospheric pressure effects on ${ }^{222} \mathrm{Rn}$ transport across the earth-air interface: Journal of Geophysical Research, v. 79, no. 33, p. 5025-5029.

Colbert, S.L., Berelson, W.M., and Hammond, D.E., 2008, Radon-222 budget in Catalina Harbor, California: 1. Water mixing rates: Limnology and Oceanography, v. 53, no. 2, p. 651-658.

Corbett, D.R., Burnett, W.C., Cable, P.H., and Clark, S.B., 1997, Radon tracing of groundwater input into Par Pond, Savannah River Site: Journal of Hydrology, v. 203, no. 1-4, p. 209-227.

Craig, H., 1969, Abyssal carbon and radiocarbon in the Pacific: Journal of Geophysical Research, v. 74, no. 23, p. 5491-5506.

Dulaiova, H., Peterson, R., Burnett, W.C., and Lane-Smith, D., 2005, A multi-detector continuous monitor for assessment of Rn-222 in the coastal ocean: Journal of Radioanalytical and Nuclear Chemistry, v. 263, no. 2, p. 361-365.

Fanning, K.A., Breland, J.A., and Byrne, R.H., 1982, Radium-226 and Radon-222 in the coastal waters of west Florida: High concentrations and atmospheric degassing: Science, v. 215, no. 4533, p. 667-670. 
Fanning, K.A., Byrne, R.H., Breland, J.A., II., Betzer, P.R., Moore, W.S., Elsinger, R.J., and Pyle, T.E., 1981, Geothermal springs of the west Florida continental shelf: Evidence for dolomitization and radionuclide enrichment: Earth and Planetary Science Letters, v. 52, no. 2, p. 345-354.

Fanning, K.A., Torres, L., and Breland J.A., II, 1987, ${ }^{226} \mathrm{Ra}$ and ${ }^{222} \mathrm{Rn}$ along Florida's coasts, in Proceedings of Symposium of Natural Radiation and Technology Enhanced Natural Radiation in Florida, May 6-8, 1987, Dayton Beach, Fla.: Winter Haven, Health Physics Society, p. 203-209.

Florida Department of Environmental Protection (FDEP), 2000, Occurrence of radon in Florida's public water supplies: FDEP, Division of Water Resource Management, $31 \mathrm{p}$.

Gruebel, K.A., and Martens, C.S., 1984, Radon-222 tracing of sediment-water chemical transport in an estuarine sediment: Limnology and oceanography, v. 29, no. 3, p. 587-597.

Hammond, D.E., Simpson, H.J., and Mathieu, G., 1977, Radon 222 distribution and transport across the sediment-water interface in the Hudson River estuary: Journal of Geophysical Research, v. 82, p. 3913-3920.

Hancock, G.J., Webster, I.T., and Stieglitz, T.C., 2006, Horizontal mixing of Great Barrier Reef waters: Offshore diffusivity determined from radium isotope distribution: Journal of Geophysical Research, v. 111, no. C12, p. C12019.

Hoehn, E., von Gunten, H.R., Stauffer, F., and Dracos, T., 1992, Radon-222 as a groundwater tracer: A laboratory study: Environmental Science \& Technology, v. 26, p. 734-738.

Hsu, S.A., Meindi, E.A., and Gilhousen, D.B., 1994, Determining the power-law wind profile exponent under nearneutral stability conditions at sea: Applied Meteorology, v. 33, no. 6, p. 757-765.

Hwang, D.W., Lee, Y.W., and Kim, G., 2005, Large submarine groundwater discharge and benthic eutrophication in Bangdu Bay on volcanic Jeju Island, Korea: Limnology and Oceanography, v. 50, no. 5, p. 1393-1403.

Johannes, R.E., 1980, The ecological significance of the submarine discharge of groundwater: Marine Ecology Progress Series, v. 3, p. 363-373.

Kroeger, K.D., Swarzenski, P.W., Greenwood, W.J., and Reich, C., 2007, Submarine groundwater discharge to Tampa Bay: Nutrient fluxes and biogeochemistry of the coastal aquifer: Marine Chemistry, v. 104, no. 1-2, p. 85-97.

Liu, Y., and Weisberg, R.H., 2007, Ocean currents and sea surface heights estimated across the West Florida Shelf: Journal of Physical Oceanography, v. 37, no. 6, p. 1697-1713.

MacIntyre, S., Wannikhof, R., and Chanton, J.P., 1995, Trace gas exchange across the air-water interface in freshwater and coastal marine environments, in Matson, P.A., and Hariss, R.C., eds., Biogenic trace gases: Measuring emissions from soil and water: Blackwell Science, p. 52-57.

Moore, W.S., 2000, Determining coastal mixing rates using radium isotopes: Continental Shelf Research, v. 20, p. 1993-2007.

Moore, W.S., and Shaw, T.J., 2008, Fluxes and behavior of radium isotopes, barium, and uranium in seven Southeastern US rivers and estuaries: Marine Chemistry, v. 108, no. 3-4, p. 236-254.

Morey, S.L., and O'Brien, J.J., 2002, The spring transition from horizontal to vertical thermal stratification on a midlatitude continental shelf: Journal of Geophysical Research, v. 107, no. C8, p. 3097.

Nelder, J.A., and Mead, R., 1965, A simplex method for function minimization: The Computer Journal, v. 7, no. 4, p. 308-313.

NOAA, 2012a, NOAA's medium resolution shoreline: Gulf of Mexico: National Oceanic and Atmospheric Administration, Coastal Geospatial Data Project, accessed September 28, 2009, at http://coastalgeospatial.noaa.gov/data_gis.html.

NOAA, 2012b, Florida and eastern Gulf of Mexico grids: National Oceanic and Atmospheric Administration, National Geophysical Data Center, accessed August 31, 2009, at http://www.ngdc.noaa.gov/mgg/coastal/grddas03/grddas03.htm.

NOAA, 2012c, NOAA's National Buoy Data Center - Historical data for Stations 42013 and 42036: National Oceanic and Atmospheric Administration, National Data Buoy Center, accessed November 3, 2009, at http://www.ndbc. noaa.gov/station page.php?station $=42013$ and http://www.ndbc.noaa.gov/ station page.php?station=42036. 
Peng, T.H., Broecker, W.S., Mathieu, G.G., Li, Y.H., and Bainbridge, A.E., 1979, Radon evasion rates in the Atlantic and Pacific Oceans as determined during the Geosecs Program: Journal of Geophysical Research, v. 84, no. C5, p. 2471-2486.

Peng, T.H., Takahash, T., and Broecker, W.S., 1974, Surface radon measurements in North Pacific Ocean Station Papa: Journal of Geophysical Research, v. 79, no. 12, p. 1772-1780.

Press, W.H., 1992, Numerical recipes in C: The art of scientific computing (2d ed.): New York, Cambridge University Press, xxvi, 994 p.

Santos, I.R., Burnett, W.C., Dittmar, T., Suryaputra, I.G.N.A., and Chanton, J., 2009, Tidal pumping drives nutrient and dissolved organic matter dynamics in a Gulf of Mexico subterranean estuary: Geochimica et Cosmochimica Acta, v. 73 , no. 5 , p. $1325-1339$.

Smith, C.G., and Swarzenski, P.W., 2012, An investigation of submarine groundwater-borne nutrient fluxes to the west Florida shelf and recurrent harmful algal blooms: Limnology and Oceanography, v. 57, no. 2, p. 471-485.

Smith, C.G., Swarzenski, P.W., Dimova, N.T., and Zhang, J., 2011, Natural radium and radon tracers to tuantify water exchange and movement in reservoirs, in Baskaran, M., ed., Handbook of environmental isotope geochemistry:

Berlin, Springer, p. 345-365.

Swarzenski, P.W., Reich, C., Kroeger, K.D., and Baskaran, M., 2007, Ra and Rn isotopes as natural tracers of submarine groundwater discharge in Tampa Bay, Florida: Marine Chemistry, v. 104, no. 1-2, p. 69-84.

\section{Additional Digital Information}

For additional information on the instrument deployments, please see:

For an online PDF version of this report, please see:

http://pubs.usgs.gov/of/2012/1212/

For more information on the U.S. Geological Survey St. Petersburg Coastal and Marine Geology

Team, please see:

http://coastal.er.usgs.gov/

\section{Direct Contact Information}

General Project Information: Christopher G. Smith (cgsmith@usgs.gov)

Regarding this Report: Christopher G. Smith (cgsmith@usgs.gov) 